\title{
Exploring data use practices around Europe: Identifying enablers and barriers
}

\author{
Kim Schildkamp*, Louisa Karbautzki, Jan Vanhoof \\ University of Twente, Faculty of Behavioural Sciences, P.O. Box 217, 7500 AE Enschede, The Netherlands
}

A R T I C L E I N F O

\section{Article history:}

Received 25 March 2013

Received in revised form 7 October 2013

Accepted 8 October 2013

Available online 14 November 2013

\section{Keywords:}

Data-based decision making

School improvement

Professional development

\begin{abstract}
A B S T R A C T
In this article we explore what data-based decision making use looks like in schools in five different countries (United Kingdom, Germany, Poland, Lithuania and the Netherlands). We explore for what purposes data are used in these countries and what the enablers and barriers to data use are. The case study results show that schools in all five countries use data for school development, accountability, and instructional improvement. Also, the schools in the five countries struggle with the same type of problems: e.g. lack of access to high quality data, lack of professional development in using data, and a lack of collaboration around the use of data. Finally, we discuss how some enablers can turn into barriers for effective data use.
\end{abstract}

(c) 2013 Elsevier Ltd. All rights reserved.

\section{Introduction and theoretical framework}

Data-based decision making is receiving increased attention in countries around the world. An important reason for this is that some studies have found that effective data use by teachers and school leaders can lead to school improvement in terms of increased student achievement (Campbell \& Levin, 2009; Carlson, Borman, \& Robinson, 2011; Lai, McNaughton, Amituanai-Toloa, Turner, \& Hsiao, 2009). Data can be defined as "information that is collected and represents some aspect of schools" (Schildkamp, Lai, \& Earl, 2013, p. 10).

Schools have access to multiple data sources: input, process, context and output data (Ikemoto \& Marsh, 2007). Input data includes, for example, data such as demographics of students. Process data refers to data such as data on the quality of instruction. Context data refers to data on policy and resources. Output data includes data such as student achievement data (Ikemoto \& Marsh, 2007).

These data can be used for decision making for school improvement. Teachers and school leaders can use data, such as assessment and survey data, for different purposes: school development purposes (e.g. policy development), instructional purposes (e.g. instructional changes, such as adapting instruction to the needs of the students), and accountability purposes (e.g. communicating results to parents) (Breiter \& Light, 2006; Coburn \& Talbert, 2006a; Diamond \& Spillane, 2004; Schildkamp \& Kuiper,

\footnotetext{
* Corresponding author. Tel.: +31 0534894203.

E-mail address: k.schildkamp@utwente.nl (K. Schildkamp).
}

2010; Schildkamp, Lai, et al., 2013; Wayman \& Stringfield, 2006; Wohlstetter, Datnow, \& Park, 2008; Young, 2006).

Furthermore, different data use studies (e.g. Coburn \& Turner, 2011; Schildkamp \& Lai, 2013; Supovitz, 2010) show that the process of data use is influenced by several factors than can either enable data use or form a barrier toward effective data use. Firstly, data use is enabled or constrained by certain school organization and context conditions. Organizational structures will influence what data are used in a school and for which purposes. A school leader can, for example, determine which data teachers have access to, they can support teachers in the use of data by means of facilitating them in time, by putting structures for data use in place, and by modeling effective data use. Furthermore, it is important that there is a shared vision in the organization, and that measurable goals exist at school, classroom, and student level. If there are no clear goals it is difficult to use data, because there are no goals to compare the data to. Moreover, if a school provides teachers with opportunities to collaborate around the use of data this can lead to more effective data use as well (Schildkamp, Poortman, \& Handelzalts, 2013). The same goes for providing teachers with training and support in the use of data (Coburn \& Turner, 2011; Datnow, Park, \& Kennedy-Lewis, 2013; Honig \& Venkateswaran, 2012; Jimerson \& Wayman, 2012; Levin \& Datnow, 2012; Mandinach \& Honey, 2008; Marsh, 2012; Schildkamp \& Kuiper, 2010; Spillane, 2012; Supovitz, 2010; Vanhoof, Verhaeghe, Van Petegem, \& Valcke, 2011; Wayman, Spring, Lemke, \& Lehr, 2012; Wayman, Jimerson, \& Cho, 2012; Wohlstetter et al., 2008; Young, 2006).

Secondly, characteristics of data and data systems can influence whether data are used for school development accountability and 
instructional purposes. Schools that have good functioning information management systems and access to relevant, reliable and valid data are more likely to show increased level of data use. Data use is likely to be constrained if teachers have difficulties in accessing the data they need, or if they feel that there are problems with the quality of the data (Breiter \& Light, 2006; Cho \& Wayman, 2013; Coburn \& Turner, 2011; Schildkamp \& Kuiper, 2010; Wayman \& Stringfield, 2006; Wohlstetter et al., 2008).

Moreover, data use is also largely dependent on characteristics of the user. School staff is made up of individual people. Some of them might have the necessary knowledge, skills and attitude to use data, whereas others may not. Several studies talk about the importance of data literacy. It takes certain knowledge and skills to analyze, interpret and take action based on data. Therefore, it is important to also look at factors at the individual data user level (Coburn \& Talbert, 2006b; Earl \& Katz, 2006; Jimerson \& Wayman, 2012; Little, 2012; Wohlstetter et al., 2008; Young, 2006).

The use of data may lead to an effect on teacher-, school leader-, and student learning. For example, based on assessment results in combination with classroom observation results, teachers can identify the needs of students (teacher learning) and address their instruction accordingly. This may lead to increased student learning and increased student achievement (Boudett \& Steele, 2007). An important question that is currently largely unanswered, however, is what types of data are used and how these data are being used or not used. A related question is which factors influence the practice of data use, as studies show that there are distinct differences in the way schools use (or not use) data, differences between schools in different countries, but also differences between schools within one country.

Therefore, this article addresses three central questions in the context of five different countries (United Kingdom, Germany, Poland, Lithuania and the Netherlands):

1. What data are used by schools in the different countries?

2. For which purposes do school leaders and teachers use data in these countries?

3. Which organizational, data and data systems and user characteristics influence the use of data?

\section{Research context and methodology}

\section{Context description}

Five countries were investigated in this study: Germany, The Netherlands, United Kingdom, Poland, and Lithuania (see also www.datauseproject.eu). In this section, we will briefly describe the policy context (in terms of autonomy, accountability, the curriculum and data available) of each country.

Germany has 16 different states and each state is responsible for providing education. The federal Ministry is mainly concerned with education research, and educational planning. Within the states, schools are centrally organized and very limited autonomy exists for schools. Decisions are mostly taken at the state, provincial/regional level and local level (OECD, 2008, 2010). Only with regard to organization of instruction the school has autonomy regarding decision making. The state designs and selects the programs that are offered and determines the range of subjects taught and the course content (OECD, 2008). Germany has a standard curriculum or partly standardized curriculum that is required, as well as mandatory national examinations and assessments (OECD, 2010). Standards are assessed by means of state-wide central tests in 9th/10th grade, as well as for Abitur (12th/13th grade). Additionally, independent state-wide central assessments are conducted in $\mathrm{K}-1$, 3rd and 8 th grade. Internal evaluations are not compulsory, but school boards and other organizations offer tools and support.

Schools in the United Kingdom have a lot of autonomy. Almost all decisions are made at the level of the school (OECD, 2008, 2010). Schools decide which textbooks they want to use, they select the programs that they will offer, decide on the range of subjects taught and the course content of these subjects (although they have to refer to a framework at the central level) (OECD, 2008). The United Kingdom does have a standard curriculum (OECD, 2010). There are national assessments required of all state schools in the United Kingdom for all students of certain ages, and although national examinations are not compulsory, only rarely do students not take core subjects as these are needed for the majority of subsequent training, education and employment needs. Schools are inspected by Ofsted, who provides schools with inspection reports. Internal evaluations using lesson observation, perception questionnaires, attainment and achievement data are highly recommended. These evaluations are most frequently based around the Ofsted inspection framework. Inspections from external evaluation agencies are optional. Schools are likely to feel pressured to use data as they are evaluated by Ofsted and their performance will appear in League tables (Downey \& Kelly, 2013). Also, the United Kingdom has a national student database, and achievement and attainment tables, which makes information available in a systematic and accessible manner.

In Lithuania, the Ministry of Education is responsible for developing educational policy, approving of the general content of teaching, organizing the final examinations, and determining the national standards for attained education level. The County's Manager's Administration implements the national education policy in the county, approves education plans for the county, and supervises the education providers. Municipalities execute the national education policy in the municipality, approve education plans, and ensure the context necessary for providing education. Also schools ensure the execution of the national education policy. At the end of secondary education, students participate in final examinations (e.g. mature exams) at school level and/or at national level (Ministry of Education and Science of the Republic of Lithuania, 2004). Schools are evaluated both externally and internally. External evaluations are carried out by the National Agency for School Assessment. Internal evaluations are obliged as well. Schools can use the internal audit methodology developed by the National Agency for internal evaluation or use their own system. Internal evaluations are carried out by the school administration in cooperation with teachers.

An important act in Poland is the Pedagogical Supervision Act passed in 2009, which lists three areas of school supervision: evaluation, control and support. The act provides also the requirements according to which all schools in Poland are externally evaluated by educational authorities. The Ministry of National Education provides curriculum standards, districts and municipalities control administration and financing, school leaders choose which teachers to hire and teachers choose a curriculum from a pre-approved list. School leaders have autonomy concerning hiring teachers, approving programs and textbooks, and conducting internal evaluations. Poland has mandatory national examinations and assessments coordinated and implemented by the Central and Regional Examination Commissions (OECD, 2010), for example the 6th (primary education), 9th (lower secondary education), and 12th grade (upper secondary education) exit exams. Schools are both (in theory) internally and externally evaluated. However, since the Act on Pedagogical Supervision is a rather new act, not all schools have been evaluated externally, nor have they conducted internal evaluations, yet.

In the Netherlands, schools have a lot of autonomy. Similar to the United Kingdom, almost all decisions are made at the level of the 
Table 1

Respondents per country.

\begin{tabular}{lccc}
\hline & Schools & School leaders & Teachers \\
\hline Germany & 2 & 6 & 6 \\
Netherlands & 6 & 21 & 11 \\
Lithuania & 2 & 15 & 0 \\
Poland & 2 & 2 & 11 \\
United Kingdom & 4 & 8 & 6 \\
Total & 16 & 52 & 34 \\
\hline
\end{tabular}

school (OECD, 2008, 2010). Schools decide which textbooks they want to use, they select the programs that they will offer, decide on the range of subjects taught and the course content of these subjects (although they have to refer to a framework at the central level) (OECD, 2008). The Netherlands does not have a standard curriculum that is required; they do have mandatory national examinations at the end of secondary education, but no other mandatory national assessments (OECD, 2010). However, schools are held accountable for their functioning by the Dutch Inspectorate. As schools are responsible for the quality of education they provide, they have to conduct some kind of school self-evaluation to check their quality and improve if necessary.

\section{Design and respondents}

Case studies were conducted in each of the five countries participating in this study. According to Yin (1984, p. 23) case studies are: "an empirical inquiry that investigates a contemporary phenomenon within its real-life context; when the boundaries between phenomenon and context are not clearly evident; and in which multiple sources of evidence are used. Stake (2000) states that a number of cases can be jointly studied to investigate a phenomenon, in this study data use in five different countries.

In each country, we aimed at studying data use in a minimum of two secondary education schools. We used purposive sampling (Yin, 2009) to identify and select schools and respondents. We were looking for schools on an advanced level in the field of databased decision making, compared to other schools in their country. These schools were identified based on (1) the project members' previous research at these sites on data use, (2) nominations from professional contacts in the field of data use research and data use support, and (3) based on policy and inspection documents. This resulted in a list of possible and willing schools in each country (see Table 1). The results can thus not be generalized to population, but they can be generalized to theoretical propositions (Yin, 2009). Our aim was to gain more insights into data use and factors influencing data use in different countries.

Interviews were conducted with respondents of each of the schools (see Table 1). These respondents included school leaders, and teachers nominated by the school leaders as having experience with data use. In Germany, six teachers and six (assistant) school leaders of two schools were interviewed. In the Netherlands, 11 teachers and 21 (assistant) school leaders of six schools were interviewed. In Lithuania, 15 (assistant) school leaders of two schools were interviewed. ${ }^{1}$ In Poland, 11 teachers and two (assistant) school leaders of two schools were interviewed. In the United Kingdom, six teachers and eight (assistant) school leaders of four schools were interviewed.

\section{Instruments}

For the interviews we used an interview schedule developed by Schildkamp and Kuiper (2010) to study the use of data and its

\footnotetext{
${ }^{1}$ It was not possible to conduct interviews with teachers in this country.
}

influencing factors. Open questions were asked with regard to what data teachers and school leaders had available, what data they used, for which purposes school leaders and teachers used data, and which variables promoted and hindered the use of data. The interviews started with an open question with regard to current school-wide school improvement initiatives, whether or not data played a role in these activities, and, if yes, how. Secondly, respondents were asked whether or not they used several data sources, such as assessment data, and for which purposes they used these data. Finally, we asked if respondents could mention factors that either enabled or hindered the use of data in their school. Interviews approximately took between 30 and 60 min. Also, documents (e.g. policy plans, literature, and OECD reports) were collected to describe the context (related to data use) in each of the countries. The data for the Dutch case studies were collected in a previous study (Schildkamp \& Kuiper, 2010).

\section{Data analyses and quality}

We used a systematized approach to data collection and analyses that is consistent with the research questions (Riege, 2003). In all countries the same interview schedule was used and the collected data were analyzed in the same manner. The interview data were coded according to a common coding scheme. The coding scheme was based on our theoretical framework. First, we coded the different types of data the respondents indicated using. We organized these data sources around input, process and context, and output data. Secondly, we looked for different purposes for data use put forward by the respondents. Examples of codes are: school development/policy development; accountability/communication with parents; instruction/instructional changes. Next, we coded the enablers and barriers for data use that the respondents mentioned. Examples of codes include: organization/school leader support; data and data systems/quality of the data; user/knowledge and skills.

For each school, the project partners conducted the coding and filled out a case specific template, including the data that were used by the schools, the school leader and teacher purpose for data use, the data and data systems characteristics, school organizational characteristics, and user characteristics influencing the use of data. For each school, one template was filled out. This facilitated the cross case analyses, for which all the case descriptions were compared and contrasted within a country and between countries. Furthermore, it enhanced validity because it made it possible to highlight major patterns of similarities and differences between respondents, schools, and countries (Poortman \& Schildkamp, 2011). For example, it enabled us to compare which factors enabled or hindered the use of data in all countries, and which factors seemed to be more unique for a certain country. The policy and inspection documents were used for describing the policy and context of each of the participating countries. The full results per country can be found in the case study report (Comenius Project Using Data for Improving School and Student Performance, 2011). In this paper we focused on the cross case analyses.

\section{Results}

Below, we describe the results of our cross case analyses. The results of the individual countries can be found in the Tables. In Section 'What data are used by school leaders and teachers in the different countries' we describe what data were used by the school leaders and teachers in the different countries. We organized these data in input, process and context, and output data. Input data includes data such as the demographics of the student population. Process data includes data on the quality of instruction. Context data includes data such as data on the curriculum, material, and 
building. Output data refers to outcomes such as student test scores and student well-being (Ikemoto \& Marsh, 2007). In Section 'For which purposes do school leaders and teachers use data in different countries?' we discuss for which purposes these data sources were used. This section is organized, according to our theoretical framework, in school development purposes, instructional purposes, and accountability purposes. In Section 'Which organizational, data and data systems, and user characteristics influence the use of data?' we present the results of the different enablers and barriers of data use, organized in school organizational characteristics, data and data system characteristics, and user characteristics.

What data are used by school leaders and teachers in the different countries

Table 2 lists the data that according to the respondents were available in their schools. Schools in all countries had a wide range of data available. All respondents mentioned the availability of input data, such as demographic information on the students in their school, process and context data (e.g. self-evaluation data), and output data (e.g. achievement results). However, the types of data that were available in Germany differed per state: both schools had student achievement results, one school had inspection and self-evaluation results. English respondents mentioned the widest range of data sources available, in terms of input data, process data and output data, although the focus was mostly on achievement data (e.g. value added achievement data, attainment data, progress data). In Lithuanian schools, there seemed to be less data available, or at least the respondents mentioned less data sources. According to the Polish respondents the data that were mostly used were achievement data. Polish schools had electronic data systems in place and teachers could access these systems to find data on their students. Schools in Poland seemed to be a bit more focused on output data, whereas in the Netherlands a wide range of process data were mentioned by the respondents.
For which purposes do school leaders and teachers use data in different countries?

With regard to using data for school development, respondents in all five countries indicated that data, such as data from internal, external evaluations and assessments, were used for policy development and school improvement planning, and for teacher development (see Table 3). However, several respondents indicated that data were used at a very superficial level. German respondents indicated, for example, that a lot of data were collected, but not systematically used. Data were mostly used for administrative purposes. The results of the interviews in the two Lithuanian schools showed that school leaders would like to use data more extensively than they currently were. In the Netherlands, several school leaders also admitted that data use usually did not move beyond the monitoring and planning stage. This was confirmed by Dutch teachers, who indicated that they were not familiar with the improvement actions formulated in policy plans and that these were often not implemented.

In Germany, Poland, and the UK, intake (assessment) data were used for placing and grouping students based on their abilities and needs. Lithuanian and UK respondents also specifically mentioned using data (e.g. assessment data, evaluation data, Ofsted inspection data) for target setting. In the case of Lithuanian schools this referred to target setting at school level, in the UK this referred to target setting for specific departments that were, according to Ofsted, underperforming. UK Respondents indicated that data were used to motivate staff, for example by celebrating achievement.

Only in the UK it seemed that schools were able to move beyond a superficial level of data use for school development. When asked for concrete examples of data use for policy and teacher development, only the UK respondents were able to deliver these. For example, they would describe how school leaders would observe a teacher's lesson and based on observation data, combined with performance data, they would discuss what types of improvements a teacher could make in the classroom. The teacher would follow up on this, and this would be evaluated again.

Table 2

Data available in each of the countries according to the respondents.

\begin{tabular}{|c|c|c|c|c|c|}
\hline & $\mathrm{GE}^{\mathrm{a}}$ & UK & LT & $\mathrm{PO}$ & $\mathrm{NL}$ \\
\hline \multicolumn{6}{|l|}{ Input data } \\
\hline Student intake/demographic data & $\mathrm{X}$ & $\mathrm{X}$ & $\mathrm{X}$ & $\mathrm{X}$ & $\mathrm{X}$ \\
\hline Special needs data & & $\mathrm{X}$ & & & \\
\hline Primary school results & & $\mathrm{X}$ & & & $\mathrm{X}$ \\
\hline Diagnostic entrance test & & & & $\mathrm{X}$ & \\
\hline \multicolumn{6}{|l|}{ Process and context data } \\
\hline Lesson observations & & $\mathrm{X}$ & & & \\
\hline External evaluations & $\mathrm{X}$ & $\mathrm{X}$ & $\mathrm{X}$ & $\mathrm{X}$ & $\mathrm{X}$ \\
\hline Self-evaluation/internal evaluation & $\mathrm{X}$ & $\mathrm{X}$ & $\mathrm{X}$ & $\mathrm{X}$ & $\mathrm{X}$ \\
\hline Teacher performance data & & $\mathrm{X}$ & & & \\
\hline Staff data, such as attendance, hours of work, degrees, age & & $\mathrm{X}$ & & & $\mathrm{X}$ \\
\hline Time spend on subjects & & $\mathrm{X}$ & & & \\
\hline Absentees/attendance data & $\mathrm{X}$ & $\mathrm{X}$ & $\mathrm{X}$ & & $\mathrm{X}$ \\
\hline Transfer data & & $\mathrm{X}$ & & & $\mathrm{X}$ \\
\hline Student behavior & $\mathrm{X}$ & $\mathrm{X}$ & & & \\
\hline School policy plans and information & $\mathrm{X}$ & $\mathrm{X}$ & $\mathrm{X}$ & & $\mathrm{X}$ \\
\hline Class management information & & $\mathrm{X}$ & & & \\
\hline Exclusion rates & & $\mathrm{X}$ & & & \\
\hline Teenage pregnancy & & $\mathrm{X}$ & & & \\
\hline Staff surveys & & $\mathrm{X}$ & $\mathrm{X}$ & & \\
\hline Student surveys and/or interviews & & $\mathrm{X}$ & & $\mathrm{X}$ & $\mathrm{X}$ \\
\hline Parent surveys and/or interviews & & $\mathrm{X}$ & $\mathrm{X}$ & & $\mathrm{X}$ \\
\hline \multicolumn{6}{|l|}{ Output data } \\
\hline School inspection report & $\mathrm{X}$ & $\mathrm{X}$ & & $\mathrm{X}$ & \\
\hline Assessment/achievement data & $\mathrm{X}$ & $\mathrm{X}$ & $\mathrm{X}$ & $\mathrm{X}$ & $\mathrm{X}$ \\
\hline School leavers & $\mathrm{X}$ & $\mathrm{X}$ & & & $\mathrm{X}$ \\
\hline Exit interviews & & $\mathrm{X}$ & & & \\
\hline Graduate surveys & & & & $\mathrm{X}$ & \\
\hline
\end{tabular}

a GE refers to Germany, UK to United Kingdom, LT to Lithuania, PO to Poland and NL to the Netherlands. 
Table 3

School development purposes for data use mentioned by the respondents per country.

\begin{tabular}{|c|c|c|c|c|}
\hline GE & UK & LT & PO & NL \\
\hline $\begin{array}{l}\text { - Policy development and school } \\
\text { improvement planning (internal } \\
\text { and external evaluations) }\end{array}$ & $\begin{array}{l}\text { - Policy development and school } \\
\text { improvement planning (internal } \\
\text { and external evaluations) }\end{array}$ & $\begin{array}{l}\text { - Policy development and } \\
\text { school improvement } \\
\text { planning (internal and } \\
\text { external evaluations) }\end{array}$ & $\begin{array}{l}\text { - Policy development and } \\
\text { school improvement } \\
\text { planning (internal and } \\
\text { external evaluations) }\end{array}$ & $\begin{array}{l}\text { - Policy development and } \\
\text { school improvement } \\
\text { planning (internal and } \\
\text { external evaluations) }\end{array}$ \\
\hline $\begin{array}{l}\text { - Teacher development } \\
\text { (assessment data) }\end{array}$ & $\begin{array}{l}\text { - Teacher development, discuss } \\
\text { and improve teacher performance } \\
\text { (lesson observations, performance } \\
\text { data and internal inspections) }\end{array}$ & $\begin{array}{l}\text { - Teacher development } \\
\text { (achievement and } \\
\text { observation data) }\end{array}$ & $\begin{array}{l}\text { - Teacher development } \\
\text { (assessment data) }\end{array}$ & $\begin{array}{l}\text { Teacher development, } \\
\text { discuss teacher } \\
\text { performance (assessment } \\
\text { data, intake transfer and } \\
\text { school leaver data) }\end{array}$ \\
\hline \multirow[t]{3}{*}{$\begin{array}{l}\text { - Grouping of students and } \\
\text { placing students (intake data) }\end{array}$} & $\begin{array}{l}\text { - Grouping of students and placing } \\
\text { students (intake data) }\end{array}$ & & $\begin{array}{l}\text { - Grouping of students } \\
\text { and placing students } \\
\text { (intake data) }\end{array}$ & \\
\hline & $\begin{array}{l}\text { Target setting for departments } \\
\text { (Ofsted reports and achievement } \\
\text { scores) }\end{array}$ & $\begin{array}{l}\text { - Target setting and } \\
\text { monitoring goals } \\
\text { (assessment data, } \\
\text { internal evaluations) }\end{array}$ & & \\
\hline & $\begin{array}{l}\text { - Motivating staff (performance data } \\
\text { and observations) }\end{array}$ & & & \\
\hline
\end{tabular}

Table 4

Instructional purposes for data use mentioned by the respondents per country.

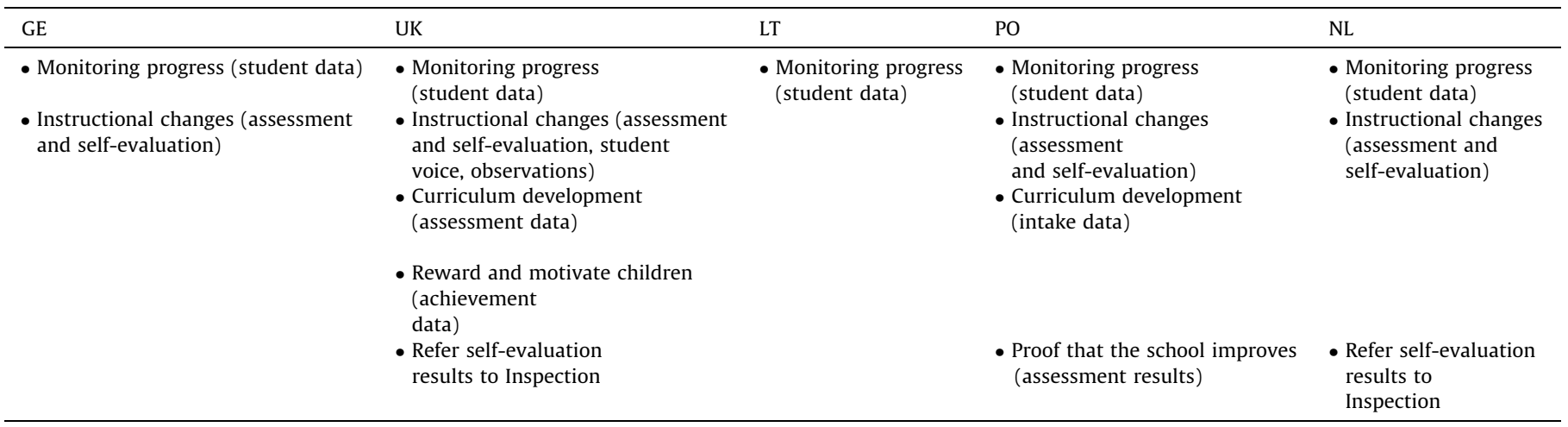

Respondents in all five countries indicated that data were used for instructional purposes (see Table 4). In all countries, student progress was monitored based on student achievement data. Respondents from Germany, the UK, Poland and the Netherlands mentioned that data were used for instructional changes. However, again, respondents from the UK were able to describe the most concrete examples (e.g. how value added assessment results were used to target instruction toward weak(er) and strong(er) students). German teachers did talk about using data to monitor progress of students and to determine the need for individual student support or instructional changes, however, this was, according to the German respondents, not common in German schools. In one of the Polish schools, respondents mentioned using data for instructional changes, such as grouping of students, monitoring progress of individual students and groups of students, and adjusting lesson plans and goals according to needs of students. Respondents from the other school mentioned that this was not common practice in Poland either. In the Netherlands, data use for instructional purposes did not move beyond monitoring in most schools. Only in two schools, teachers could name concrete examples of how data were used to make instructional changes. For example, one teacher talked about analyzing the assessment results of failing students, discovering that these students all failed specific topics, and then re-teaching these topics, but explaining these topics in a different manner.

Also, respondents in all five countries mentioned using data for accountability purposes (see Table 5). Specifically, results of

Table 5

Accountability purposes for data use mentioned by the respondents per country.

\begin{tabular}{|c|c|c|c|c|}
\hline GE & UK & LT & $\mathrm{PO}$ & $\mathrm{NL}$ \\
\hline \multirow[t]{3}{*}{$\begin{array}{l}\text { - Communication with } \\
\text { parents (student data) } \\
\text { - Public relations } \\
\text { (administrative data) }\end{array}$} & $\begin{array}{l}\text { - Communication with } \\
\text { parents (student data) }\end{array}$ & $\begin{array}{l}\text { - Communication with } \\
\text { parents (student data) }\end{array}$ & $\begin{array}{l}\text { - Communication with } \\
\text { parents (student data) }\end{array}$ & $\begin{array}{l}\text { - Communication with } \\
\text { parents (student data) } \\
\text { - Public relations (inspection } \\
\text { results) }\end{array}$ \\
\hline & & $\begin{array}{l}\text { - Communication and } \\
\text { collaboration with other schools } \\
\text { (achievement } \\
\text { and evaluation data) }\end{array}$ & & \\
\hline & $\begin{array}{l}\text { - Refer self-evaluation } \\
\text { results to Inspection }\end{array}$ & & $\begin{array}{l}\text { - Proof that the school improves } \\
\text { (assessment results) }\end{array}$ & $\begin{array}{l}\text { - Refer self-evaluation } \\
\text { results to Inspection }\end{array}$ \\
\hline
\end{tabular}


Table 6

Organizational characteristics influencing data use according to the respondents.

\begin{tabular}{|c|c|c|c|c|c|}
\hline & GE & UK & LT & PO & NL \\
\hline Teacher collaboration and colleague support & - & + & + & $+1-$ & $+1-$ \\
\hline Data expert & - & + & - & & + \\
\hline Vision and goals for data use & $+1-$ & + & + & & $+1-$ \\
\hline School leader support & & & & +- & $+1-$ \\
\hline Training and support in data use & - & + & - & - & - \\
\hline Time & - & $+1-$ & - & + & - \\
\hline
\end{tabular}

Table 7

Data and data system characteristic influencing data use according to the respondents.

\begin{tabular}{|c|c|c|c|c|c|}
\hline & GE & UK & LT & $\mathrm{PO}$ & $\mathrm{NL}$ \\
\hline Availability of and access to different types of data & $+1-$ & + & - & + & $+1-$ \\
\hline Quality of the data & $+1-$ & $+1-$ & $+1-$ & + & $+1-$ \\
\hline Data system, tools and software & - & + & & & \\
\hline
\end{tabular}

students were communicated to parents (in all countries), sometimes shared with other schools (UK and Lithuania), and if the results were good they were used for public relation purposes in Germany and the Netherlands (e.g. post high achievement results on the school's website or share the results in newsletters to the community). Data were also used to comply with accountability demands of an inspectorate or ministry. In the UK and the Netherlands, for example, school self-evaluation results were sent to the inspectorate.

Which organizational, data and data systems, and user characteristics influence the use of data?

Tables 6-8 compare the results per country for the different influencing factors (e.g. school organizational characteristics, data and data system characteristics, and user characteristics). In the tables, it is indicated whether a factor enabled (+) or hindered (-) the use of data according to the respondents. For example, some respondents in the Netherlands indicated that they felt supported by their colleagues in the use of data $(+)$, whereas other respondents in the Netherlands felt not supported in the use of data by their colleagues (-). If a factor is not mentioned at all by any of the respondents in a country the cell is left empty (e.g. we did not ask questions about all of the factors, but asked an open question with regard to what factors the respondent could mention that either enabled or hindered data use in their school or classroom).

Table 6 shows that organizational characteristics of influenced data-based decision making in the five countries. The following organization variables were mentioned by the respondents as either enabling or hindering factors in the use of data. German respondents stated that they were not collaborating around the use of data. In some schools teachers collaborated around the use of data in the Netherlands, but this was not common. Several teachers complained about the lack of collaboration around the use of data and a lack of support from their colleagues. In the UK, teacher collaboration around data use was common. Teachers collaborated around the analysis, interpretation and use of data in, for example, subject matter teams, grade level teams or data teams. Lithuanian respondents also indicated that they collaborated around the use of data. Teachers in Poland collaborated around the use of data, usually in subject specific team meeting, where student outcome data was analyzed, sometimes at the request of the school leader. However, most of the communication took place by e-mail or by informal communication.

In the Netherlands and the UK, some respondents indicated that there was a data expert available to answer their questions about data use. In the Netherlands, this was in the form of a so-called quality manager. However, this person often worked not at the school, but at the level of the school board, and only school leaders turned to this person for help around the use of data. In the UK schools the data experts worked at the school and teachers could also turn to these persons for help. The data experts in these schools were members of school staff, deputy and assistant head teachers, who were appointed to the role of data manager or data administrator, but had other responsibilities in the school as well. They were, for example, responsible for the input, warehousing and exchange of data. These data experts could provide the needed data in a timely matter, as well as assist in analyzing, interpreting, and using data.

In Germany, a lack of a clear vision and goals hindered the use of data. German respondents mentioned that a general strategy of the education authorities with regard to data use was missing. Often no specific instruction or targetable improvement values or goals had been formulated. Only some respondents indicated that in their school they had clear and measurable goals. In some schools in the Netherlands a clear vision, norms and goals existed, in other schools not. UK and Lithuanian respondents mentioned that having a clear vision and goals was important in their schools. Respondents in both countries talked about using data to monitor the implementation of these vision and goals.

Some Dutch and Polish respondents talked about how their school leaders actively supported, encouraged and facilitated the use of data. One of the Polish school leaders coordinated and supported the work of the teams in one of the schools. He provided structures, put processes in place, participated in meetings, supported the development of an improvement plan, and monitored the implementation. However, in the other Polish school the school leader did not put in place a structured process

Table 8

User characteristic influencing data use according to the respondents.

\begin{tabular}{|c|c|c|c|c|c|}
\hline & GE & UK & LT & PO & NL \\
\hline Attitude toward data & + & + & + & + & $+1-$ \\
\hline Knowledge and skills for data use & - & $+1-$ & - & $+1-$ & - \\
\hline
\end{tabular}


for data use and monitoring. In the Netherlands, several respondents also indicated that their school leader encouraged the use of data, although some respondents indicated that they did not feel supported by their school leader.

In Germany, little to no support exists for schools in the use of data. Training in data use happened sporadically and was usually linked to studies conducted by external parties. After the evaluation of national test results, for example, the executing institutes offered workshops. No nationwide training was established. UK respondents indicated that they had received extensive training in data use, and that they also received support from their Local Education Authority. However, several respondents indicated that they still found it difficult to come up with improvement measures based on data. Professional development around the use of data was not a standard offering to teachers or school leaders in Poland. Only motivated and innovative teachers and school leaders developed competencies in this area, mainly through pursuing conference participation or individual reading and on-the-job learning. However, the drive toward developing data use competencies was gradually increasing as the state exam data and value added data were gaining more attention and are subject of various regional or state-level analyses. Dutch and Lithuanian teachers indicated having received no training.

Respondents in all countries complained about a lack of time to use data. In some UK schools and in one of the Polish schools structured time was set aside to use data and structured processes for data use existed within the school.

Several respondents talked about how different data and data systems influenced the use of data (see Table 7). Interestingly, some enabling factors could also form barriers to the use of data. For example, respondents in the Netherlands talked about the importance of having different types of data available (e.g. not only assessment data), but other respondents talked about how the availability of a wide range of different data sources could become a barrier to data use as respondents indicated that they felt like they were "drowning in data" or experienced "information overload, because there was too many data out there". German respondents complained that were several data sources out there, but that they had only limited access to data, especially when it concerned student data. This was related to strict privacy policies around student data. Moreover, in Germany data, such as final examination results, were not always timely available. UK and Polish respondents indicated that their schools had access to a wide range of data sources, although Polish respondents talked mostly only about assessment data. Lithuanian respondents indicated that there were problems with the availability of data.

Several respondents talked about problems with the quality of data. For example, in Germany, the data collection for the national learning performance measurements is carried out within the school and is very error-prone, resulting in low quality data. In the UK, the quality of data was usually good, although respondents sometimes complained about the lack of timely and accurate data (for example, they could not always use estimates of attainment, because these are influenced by deprivation factors). Lithuania respondents indicated that data were always relevant. The fact that Lithuanian schools were able to use data to some extent was probably due to the fact that both the external and internal evaluation resulted in usable, relevant, reliable and accurate data. In the Netherlands, respondents stated that there were some problems with timely and relevant data that coincides with the needs of the user. The only respondents that seemed to be completely satisfied with the quality of the data (and specifically the quality of the value added student achievement data) were the Polish respondents.

UK respondents talked about the data systems, tools, and software available in their schools. Mostly, UK respondents indicated that with these systems they were able to find the data they need easily and timely. Some departments even had department specific data systems aligned with their needs. Finally, they had tools available to analyze and use data. According to German respondents, there was a problem of interoperability between the different data systems in their schools. Hence, the relation between different data could not be analyzed. German information systems are heterogeneous and teachers selected their own tools which did not fit to the central information systems. There were no data standards and the ICT infrastructure for administrative purposes in schools did not allow collaborative or individual data use.

Finally, respondents mentioned several user characteristics as enabler or barriers. A positive attitude toward data use was mentioned by respondents in all countries as an enabling influence on data use (see Table 8). In two Dutch schools, respondents showed a more negative attitude toward the use of data. One respondent mentioned that he "did not believe in the use of data". Another teacher indicated that "assessment results are different each year, depending on whether you have good or not so good students".

Also, school staff need knowledge and skills to collect, analyze, interpret and use data. German, Dutch and Lithuanian respondents indicated that they lacked data analysis and data use skills. UK respondents indicated that they were trained in the use of data and possessed the knowledge and skills needed to use data effectively. Respondents of one Polish school indicated that they needed to work on their skills to use data, respondents of the other school indicated that they had the knowledge and skills needed to work with data, as these teachers were certified examiners.

\section{Conclusion and discussion}

Before discussing the results, we have to discuss the limitations of this study. First of all, the schools that participated are not a representative sample, but were selected because they are good examples of how data is used in each of the countries. We want to emphasize that the goal of this part of the project was not to make firm generalizations, but to gain more insights into the use of data in different countries. Teachers' and school leaders' self-perception is used to study their use of data. We checked the comments made by the respondents by asking for more details and by asking for examples.

By identifying the purposes for which data are being used in schools it may seem that we present data use as a rather linear, rational process, which it is not. Data use involves a number of processes, conditions and contexts which interact in complex ways and context interacts with user characteristics, data use and stakeholder learning. Data use involves an interpretative process, in which data has to be identified, collected, analyzed and interpreted to become meaningful and useful for actions (Coburn \& Turner, 2011; Coburn, Toure, \& Yamashita, 2009). All factors (data use, organizational characteristics, data characteristics, user characteristics) are interlinked and can influence each other.

Our first research question was "what data are used by schools in the different countries?". The results of our study show that schools in the five European countries have a wide range of data available to them. The respondents of the UK mentioned the widest range of data available, which is not surprising, as this country also has the longest European tradition in data use. The focus seemed to be mostly on value added achievement data, attainment data, and progress data, although respondents also indicated that a wide range of input, process and context data were available. In our view, the narrow focus on achievement data can lead to a narrow form of data-based decision making focusing predominantly on cognitive outcomes. We would argue that data should be used to determine whether or not a wider set of outcomes are being 
reached, and if not, take action accordingly. Several of these goals pertain to student achievement, but schools pursue other outcomes as well, for example with regard to emotional well-being of students, social skills, and citizenship competences.

German and Lithuanian respondents mentioned the least amount of data sources. The question is whether these other data sources do not exists, respondents do not have access to these data sources, or respondents do not know these data sources exists. In the case of Germany, respondents did indicate that problems existed with regard to access to different data sources due to strict privacy policies.

Our second research question was "for which purposes do school leaders and teachers use data in these countries?". With regard to the purposes of using data for school and instructional improvement, respondents in all countries talked about the use of data for policy development, school improvement planning, teacher development and instructional improvement. However, in all the countries, with the exception of the UK, data used seemed to be used at a very superficial level and did not move beyond the monitoring phase. Respondents from the UK were able to describe the most concrete examples (e.g. how value added assessment results were used to target instruction toward weak(er) and strong(er) students). Most respondents from the other countries were not able to provide concrete examples of how identified weaknesses based on data let to actions in the classroom, although there were some exceptions from Dutch and Polish respondents.

Data use for accountability was common in all five countries. The fact that the focus of the use of data in all five countries seems to be more on accountability than on school development and instructional improvement is worrisome. In every country it is important to hold schools accountable for their functioning, but this should neither be the sole nor the most important aspect of data use. The focus should be on the use of data for improvement. A sole focus on data use for accountability also comes with a danger of negative side effects. In the United States, we have seen several examples of these negative side effects, including focusing only on a specific type of students who can help improve your status on accountability indicators (e.g. bubble kids), cheating to improve the status on accountability indicators, teaching to the test, excluding certain students from a test, and encouraging low performing students to drop out (Ehren \& Swanborn, 2012; Hamilton, Stecher, \& Yuan, 2009).

With regard to our third research question, "which organizational, data and data systems and user characteristics influence the use of data?", the results show that all three factors influence the use of data. The results of this study also provide us with some insight into why several schools are not using data for improvement purposes, especially when we compare the schools in the Netherlands, Germany, Poland and Lithuania with the schools in the UK. UK schools seem much more equiped to use (student achievement) data effectively, as several organizational structures were put in place in UK schools. Important differences with the other four countries include that in UK schools, respondents collaborated around the use of data, for example in grade levels, they had a data expert available on site, and mabybe the most important difference, UK respondents indicated that they were trained in the use of (achievement) data.

Another important difference between the UK and the other four countries pertains to data and data system characteristics, specifically data information systems, tools, and software to analyze data. In the UK, teachers had access to very sophisticated systems and tools, although some respondents indicated not knowing how to use these, in which case access to these systems and tools became a barrier instead of an enabler. In the other countries, schools did not have these sophisticated systems and tools available. For example, In German schools there was a problem of interoperability between the different data systems in their schools, and teachers were not able to combine and analyze certain types of data.

What is striking is that the availability of different types of data, which is generally seen as an enabling factor, can also form a barrier to data use. In the Netherlands, for example, some respondents indicated that there was too much data out there, and they did not know where to start. Datnow et al. (2013) talk about similar findings in their study in which several factors can become an affordance (enabler) or constraint (barrier). They, for example, found that providing teachers with time for collaboration around data use, and protocols and structures with regard how to use data, generally seen as enablers, sometimes worked as barriers as teachers felt that there was yet another thing imposed on them. As stated by Datnow et al. (2013, p. 346): "some of the very same conditions can be both an affordance and constraint at the same time. A great deal depends on the context in which the work takes place, as well as individuals' experiences and knowledge."

The final importance difference we found between the countries is that respondents in the UK and Poland indicated having the knowledge and skills to analyze and use data, although in Poland this pertained to analyzing specific assessment data by certified examiners. Respondents from the other countries indicated lacking knowledge and skills to use data effectively (e.g. data literacy), which is also a result of a lack of training.

The results of this study confirm that organizational, data and data system, and user characteristics all influence the use of data in the different schools in the different countries. However, in one country or school a factor can work as a enabler (e.g. access to different types of data) whereas in another school or in another country that same factor can be absent or work as a barrier (e.g. there is too much data out there). Whether a factor works as an enabler or barrier can also depend on the data user. In the case of our example, the user does not know where to start because there is too much data out there. It can also depend on the organization. In our example, the school could streamline the data and provide users with access to data that are relevant to them.

Although it was not the explicit aim of this study we did notice that pressure from the accountability system seemed to play an important role in all countries. However, in the UK pressure was combined with support. Effective data use probably requires some pressure from the accountability system, but is needs to be combined with support in terms of a good functioning data system, data analyses tools, and professional development in the use of data (Schildkamp \& Lai, 2013).

Also, the amount of autonomy schools have in decision making can affect data use. In the United Kingdom and the Netherlands, schools have a lot of autonomy and they can make almost all decisions themselves (with regard to the curriculum, instruction, personnel and resources). In Germany, schools have a lot less autonomy. A lack of autonomy in Germany may have hindered the use of data, simple because school leaders and teachers were often not allowed to make certain decisions. If you combine this with a lack of data literacy, and very strict privacy policies which prevent access to several student sources, it is easy to understand why German respondents indicated that data were not used a lot.

It is important to note that there is a difference between the actual availability of policy space and the experienced policy space. In schools in the United Kingdom and in the Netherlands ample policy space exists for schools to make all sorts of decisions based on data, for example with regard to the curriculum, instruction, and even with regard to attainment targets to some extent. For example, in the Netherlands, over the years schools have received more policy space. The number of attainment targets decreased from 122 (in 1993) to 58. Furthermore, the attainment targets that still exist are much less detailed and do not specify teaching methodologies. These attainment targets are meant as a source of 
inspiration for schools to base decisions on. They do still form a frame of reference for accountability, for example with regard to outcomes (Nieveen \& Kuiper, 2012). However, this objective policy space might differ from the perception of this policy space. Several schools and teachers do not perceive having this policy space (Nieveen \& Kuiper, 2012; Nieveen, Van den Akker, \& Resink, 2010), and consequently are not inclined to make decision with regard to the curriculum and instruction based on data.

What is interesting to note is that although there were huge variations in the contexts of schools participating in this study, almost all the respondents acknowledged the importance of data use, and also acknowledged the problems with data use in their schools. The most common problems were problems with access to data and appropriate data systems and tools, a lack of knowledge and skills in the use of data (and related to this a lack of professional development and training in the use of data), a lack of teacher collaboration. Therefore, we believe that the way forward is to invest in professional development of teams of teachers and school leaders in the use of data.

Professional development in the use of data is urgently needed and is crucial for improving the quality of schools (Desimone, 2009; Van Veen, Zwart, Meirink, \& Verloop, 2010). These professional development activities of course need to take into account the context of the school and country, but we believe that these activities can look similar in all of the countries. As results from this study indicate, teachers and school leaders sometimes do not know with what data to start. Paradoxically, we believe that the best way to start with data use is not to start with data but to start with a problem a school wants to solve or goals they want to achieve. The next step is collecting data on these problems and goals. This approach can work in all countries around the globe, but only if we invest in training for data literacy and invest in an effective data infrastructure.

\section{Acknowledgements}

This paper includes parts of the reports "Comparative analyses data use in Germany, The Netherlands, Lithuania, Poland and England", workpackage lead: Dr Kim Schildkamp, University of Twente and "Survey Data Analysis", workpackage lead: ifib Institute for Information Management Bremen $\mathrm{GmbH}$. The authors of these reports are: PCG Polska (PL), Specialist Schools and Academies Trust (UK), Modern Didactics Center (LT), University of Twente (NL), Institute for Information Management Bremen $\mathrm{GmbH}$ (GE). All rights reserved to DATAUSE project partners. More information can be found here: www.datauseproject.eu. The DATAUSE project has been funded with support from the European Commission. This communication reflects the views only of the authors, and the Commission cannot be held responsible for any use which may be made of the information contained therein.

\section{References}

Boudett, K. P., \& Steele, J. L. (2007). Data wise in action. Stories of schools using data to improve teaching and learning. Cambridge: Harvard Education Press.

Breiter, A., \& Light, D. (2006). Data for school improvement: Factors for designing effective information systems to support decision-making in schools. Educationa Technology \& Society, 9(3), 206-217.

Campbell, C., \& Levin, B. (2009). Using data to support educational improvement. Educational Assessment, Evaluation and Accountability, 21(1), 47-65.

Carlson, D., Borman, G., \& Robinson, M. (2011). A multistate district-level cluster randomized trial of the impact of data-driven reform on reading and mathematics achievement. Education and Evaluation and Policy Analysis, 33(3), 378-398.

Cho, V., \& Wayman, J. (2013). Data systems and sensemaking. Teachers College Record. (in press).

Coburn, C. E., \& Talbert, J. E. (2006a). Conceptions of evidence use in school districts: Mapping the terrain. American Journal of Education, 112, 469-495.

Coburn, C. E., \& Talbert, J. E. (2006b). Conceptions of evidence use in school districts: Mapping the terrain. American Journal of Education, 112(4), 469-495.
Coburn, C. E., Toure, J., \& Yamashita, M. (2009). Evidence, interpretation, and persuasion: Instructional decision making in the district central office. Teachers College Record, 111(4), 1115-1161.

Coburn, C. E., \& Turner, E. O. (2011). Research on data use: A framework and analysis. Measurement, 9, 173-206.

Comenius Project Using Data for Improving School and Student Performance. (2011). Comparative analyses data use in Germany, The Netherlands, Lithuania, Poland and The United Kingdom. Accessible at: http://www.datauseproject.eu/ Retrieved 16.11.13.

Datnow, A., Park, V., \& Kennedy-Lewis, B. (2013). Affordances and constraints in the context of teacher collaboration for the purpose of data use. Journal of Educational Administration, 51(3), 341-362.

Desimone, L. M. (2009). Improving impact studies of teacher's professional development: Toward better conceptualizations and measures. Educational Researcher, 38(3), 181-199.

Diamond, J. B., \& Spillane, J. P. (2004). High-stakes accountability in urban elementary schools: Challenging or reproducing inequality. Teachers College Record, 106(6), $1145-1176$.

Downey, C., \& Kelly, A. (2013). Professional attitudes to the use of data in England. In K. Schildkamp, M. K. Lai, \& L. Earl (Eds.), Data-based decision making in education: Challenges and opportunities (pp. 69-89). Dordrecht: Springer.

Earl, L., \& Katz, S. (2006). Leading in a data rich world. Thousand Oaks, CA: Corwin Press.

Ehren, M. C. M., \& Swanborn, M. S. L. (2012). Strategic data use of schools in accountability systems. School Effectiveness and School Improvement, 23(2), 257-280.

Hamilton, L. S., Stecher, B. M., \& Yuan, K. (2009). Standards-based reform in the United States: History, research, and future directions. Santa Monica, CA: RAND Corporation. Retrieved from http://www.rand.org/pubs/reprints/RP1384.

Honig, M. I., \& Venkateswaran, N. (2012). School-central office relationships in evidence use: Understanding evidence use as a systems problem. American Journal of Education, 118(2), 199-222.

Ikemoto, G. S., \& Marsh, J. A. (2007). Cutting through the data-driven mantra: Different conceptions of data-driven decision making. In P. A. Moss (Ed.), Evidence and decision making. USA: Wiley-Blackwell.

Jimerson, J. B., \& Wayman, J. C. (2012). Branding educational data use through professional learning: Findings from a study in three districts. Paper presented at the American Educational Research Association Conference.

Lai, M. K., McNaughton, S., Amituanai-Toloa, M. Turner, R. \& Hsiao, S. (2009). Sustained acceleration of achievement in reading comprehension: The New Zealand experience. Reading Research Quarterly, 44(1), 30-56.

Levin, J. A., \& Datnow, A. (2012). The principal role in data-driven decision making: Using case-study data to develop multi-mediator models of educational reform. School Effectiveness and School Improvement, 23(2), 179-202.

Little, J. W. (2012). Understanding data use practice among teachers: The contribution of micro-process studies. American Journal of Education, 118(2), 143-166.

Mandinach, E. B., \& Honey, M. (Eds.). (2008). Data driven school improvement: Linking data and learning. New York: Teachers College Press.

Marsh, J. A. (2012). Interventions promoting educators' use of data: Research insights and gaps. Teachers College Record, 114(11), 1-48.

Ministry of Education and Science of the Republic of Lithuania. (2004). Education in Lithuania. Vilnius: Ministry of Education and Science of the Republic of Lithuania.

Nieveen, N., \& Kuiper, W. (2012). Balancing curriculum freedom and regulations in the Netherlands. European Educational Research Journal, 11(3), 357-368.

Nieveen, N., Van den Akker, J., \& Resink, F. (2010). School-based curriculum development in the Netherlands. Paper presented at the European Conference on Educational Research (ECER).

OECD. (2008). Education at a glance 2008: OECD indicators. Paris: Organisation for Economic Co-operation and Development (OECD)

OECD. (2010). Education at a glance 2010: OECD indicators. Paris: Organisation for Economic Co-operation and Development (OECD)

Poortman, C. L., \& Schildkamp, K. (2011). Alternative quality standards in qualitative research? Quality and Quantity, 46(6), 1727-1751.

Riege, A. M. (2003). Validity and reliability tests in case study research: A literature review with hands-on applications for each research phase. Qualitative Market Research: An international Journal, 6(2), 75-86.

Schildkamp, K., \& Kuiper, W. (2010). Data informed curriculum reform: Which data, what purposes, and promoting and hindering factors. Teaching and Teacher Education, 26, 482-496.

Schildkamp, K., Lai, M. K., \& Earl, L. (2013a). Data-driven decision making around the world: Challenges and opportunities. Dordrecht: Springer.

Schildkamp, K., \& Lai, M. K. (2013). Data-based decision making: Conclusions and theoretical framework. In K. Schildkamp, M. K. Lai, \& L. Earl (Eds.), Data-based decision making in education: Challenges and opportunities PL Dordrecht (pp. 177191). Springer

Schildkamp, K., Poortman, C. L., \& Handelzalts, A. (2013b). Data teams for school improvement. Teaching and Teacher Education. (submitted for publication).

Spillane, J. P. (2012). Data in practice: Conceptualizing the data-based decision making phenomena. American Journal of Education, 118(2), 113-141.

Stake, R. E. (2000). Case studies. In N. K. Denzin \& Y. S. Lincoln (Eds.), Handbook of qualitative research (pp. 435-454). Thousand Oaks, CA: Sage Publications.

Supovitz, J. (2010). Knowledge-based organizational learning for instructional improvement. In A. Hargreaves, A. Lieberman, M. Fullan, \& D. Hopkins (Eds.), Second international handbook of educational change (pp. 707-723). New York: Springer.

Vanhoof, J., Verhaeghe, G., Van Petegem, P., \& Valcke, M. (2011). The influence of competences and support on school performance feedback use. Educational Studies, 37(2), 141-154. 
Van Veen, K., Zwart, R., Meirink, J., \& Verloop, N. (2010). Professionele ontwikkeling van leraren. Een reviewstudie naar effectieve kenmerken van professionaliseringsinterventies van leraren [Professional develoment of teachers. A review into effective characteristics of professional development interventions]. ICLON/Expertisecentrum Leren van Docenten.

Wayman, J. C., \& Stringfield, S. (2006). Data use for school improvement: School practices and research perspectives. American Journal of Education, 112, 463-468.

Wayman, J. C., Spring, S. D., Lemke, M. A., \& Lehr, M. D. (2012a). Using data to inform practice: Effective principal leadership strategies. Paper presented at the American Educational Research Association Conference.
Wayman, J. C., Jimerson, J. B., \& Cho, V. (2012b). Organizational considerations in establishing the data-informed district. School Effectiveness and School Improvement, 23(2), 159-178.

Wohlstetter, P., Datnow, A., \& Park, V. (2008). Creating a system for data-driven decision-making: Applying the principal-agent framework. School Effectiveness and School Improvement, 19(3), 239-259.

Yin, R. K. (1984). Case study research: Design and methods. Beverly Hills, CA: Sage Publications.

Yin, R. K. (2009). Case study research (4th ed.). Beverly Hills, CA: Sage Publications.

Young, V. M. (2006). Teachers' use of data: Loose coupling, agenda setting, and team norms. American Journal of Education, 112, 521-548. 